\title{
Managing the Financial Stress Generated by the COVID-19 Pandemic in the Public System. Solutions for Economic Restart in Romania
}

\author{
Cristian MIRICA ${ }^{\star}$, Monica Laura ZLATI ${ }^{\star \star}$, Angela Eliza MICU ${ }^{\star \star \star}$, Silvius STANCIU ${ }^{\star \star \star \star}$, \\ Violeta SAPIRA ${ }^{\star \star \star \star \star}$, Andrei Mirel FLOREA ${ }^{\star \star \star \star \star \star}$
}

\begin{tabular}{l}
\hline \multicolumn{1}{c}{ A R T I C L E I N F O } \\
\hline Article history: \\
Accepted April 2020 \\
Available online May 2020 \\
\hline JEL Classification \\
G01, I15 \\
Keywords: \\
Economic crisis, Pandemic, SARS \\
Cov-2, Financial stress, Economic \\
solution, Statistical model
\end{tabular}

1. Introduction

The current socio-economic context in Romania is dominate by the medical crisis, with an impact on the income and health of the population, especially on adults and the elderly. The public measures to reduce the impact of the health crisis aimed in a first stage to limit the spread of the virus, through measures of quarantine, isolation and social distancing and to stop the economic activity in the secondary and tertiary sector. After the end of the emergency state instituted through presidential decree, the gradual resumption of the activity of the affected sectors is target, depending on the dynamics of the virus spread in each region, corroborated with economic revival measures and support. From a medical point of view, the evolution of the virus in Romania was relatively moderate, our country being among the first 30 states in what concerns the level of virus spread amid the population measured by the number of sick people, with less than a thousand deaths. Compared to the population of Romania of 19.5 million inhabitants, this rate is below 1\%, with a number of diseases of up to 15,000 cases (infection rate below $1 \%$ of the country's population). The economic context generated by the COVID 19 pandemic is unfavourable for our country. Following a constant growth of the economy with an annual average of $4-5 \%$ in the last period, and a rise in consumer demand, Romania has been face with an economic crisis. This crisis, has reduced revenues and maximized expenses at the budgetary level, such that the administrative and fiscal apparatus in Romania is currently prone to high financial stress, which must be manage through viable and realistic measures, while ensuring the security and health of the population. In this context, the study conducted by the authors is of particular importance, the proposed model meeting the steps of the competent authorities to calm the economic recession and revive economy through specific measures.

\section{Literature review}

In the economic literature, experts such as Atkeson (2020) believe that the economic recovery overlaps to some extent with the Marcov chains, adjusted with the social distancing related to coronavirus infections and the rate of contagion spread among the population. Thus, Fergusson discusses a model based on the impact of public health on economic recovery measures (Ferguson et al., 2020). McKibbin \& Fernando (2020) $\star{ }^{\star}{ }^{\star \star \star \star},{ }^{\star \star \star \star \star \star},{ }^{\star \star \star \star \star \star}$ Dunarea de Jos University of Galati, Romania, ${ }^{\star \star}$ Stefan cel Mare University of Suceava, Romania, ${ }^{\star \star \star}$ Ovidius University of Constanta, Romania. E-mail
addresses: floreaandreim@yahoo.com (A.M. Florea - Corresponding author), expertcris13@gmail.com (C. Mirica), sorici.monica@usm.ro (M. L. Zlati), angelaelizamicu@yahoo.com (A.E. Micu), silvius.stanciu@ugal.ro (S. Stanciu), violeta.sapira@ugal.ro (V. Sapira). 
elaborated analyses of the impact of the Covid-19 pandemic in the following period and highlighted its threats on the public health system and on the economy as a whole. Barro, Ursua, \& Weng (2020) have made correlations with the Spanish flu to estimate and highlight the impact of the pandemic on the economy. In crisis situations, FMCG purchases do not follow a normal trend, with food, personal care products and health care being especially preferred. The government must act in the market to limit rising prices and meet the needs of the population (Stanciu et al, 2019; Antohi et al, 2019).

The scenarios proposed by Anderson, Heesterbeek, Klinkenberg, \& Hollingsworth (2020) showed the onset of economic recession at the beginning of the growth curve of Covid-19 spread in the economy. This economic strain reaches its peak only at two or three spread intervals, in other words, if the coronavirus pandemic lasted 3 months in an analysed geographical area, the boom of the economic crisis would occur after 12 months. Conclusions drawn by international specialist's show that in this equation the medical system is the link that generates the worst consequences on the economic situation.

Other authors analyse a parallel between the impact of the coronavirus in China and the United States to identify the main causes of pandemic amplification in the United States compared to China, South Korea or even Singapore (Atkeson, 2020). Research conducted by Stanciu (2015) showed that in Romania SME' $s$ and public institutions are not prepared to deal with crisis situations, and government support is needed to overcome them.

In Romania, in order to eliminate the effects of the pandemic, a series of normative acts were issued in the form of Government Emergency Ordinances GEO 29/2020 (Government of Romania, 2020a), GEO 33/2020 (Government of Romania, 2020b), GEO 48/2020 (Government of Romania, 2020c). These Ordinances have consequences, in the first stage, the reduction of the fiscal pressure on the employers. the exemption from the payment of some taxes (the aim being to protect the population affected by unemployment by granting compensatory payments during the crisis period), the adoption of additional allocations toward the health system through the centralized procurement system, aiming at the purchase of protective equipment and disinfectants to support the medical staff in the fight against coronavirus.

Government Emergency Ordinance no. 29/2020 (Government of Romania, 2020a), stipulates a number of economic and fiscal - budgetary measures:

- modifies the period in which debtors who wish to restructure their budgetary obligations has the obligation to notify the competent fiscal body about their intention

- modifies the deadline by which the request for restructuring can be submitted under the sanction of forfeiture

- the due tax obligations starting with the date of entry into force of the emergency ordinance, unpaid within 30 days from the end of the state of emergency, are not considered outstanding tax obligations and no interest and delay penalties are calculated or due according to the provisions of the Fiscal Procedure Code

- suspension or halt of any mandatory execution measures seizing the budget receivables, except for those ruled by court decisions pronounced in criminal matters

Government Emergency Ordinance no. 33/2020 (Government of Romania, 2020b) regarding some

fiscal measures and the amendment of some normative acts (M. O. no. 260 of March 30, 2020) includes:

- Regulates a series of bonuses for profit tax payers / micro-enterprise income tax / specific tax, in order to stimulate the payment of due tax obligations, as follows:

o Taxpayers paying profit tax, regardless of the declaration and payment system provided by art. 41 of Law no. 227/2015 on the Fiscal Code, as subsequently amended and supplemented, which pay the tax due for the first quarter of 2020, respectively for the advance payment for the same quarter, until the due date of April 25, 2020 inclusively, benefit from a bonus calculated on the tax on due profit as follows:

a) 5\% for large taxpayers established by the Order of the President of the National Agency for Fiscal Administration no. 3,609 / 2016 regarding the organization of the administration activity of the big taxpayers

b) $10 \%$ for medium taxpayers established by the Order of the President of the National Agency for Fiscal Administration no. 3,610/2016 regarding organization of the activity of managing medium taxpayers, with subsequent amendments

c) $10 \%$ for the other taxpayers who do not fall under letters a) and b).

- Taxpayers paying tax on the income of micro-enterprises, who pay the tax for the first quarter of 2020, by April 25, 2020 inclusively, receive a bonus of $10 \%$ calculated on the tax due for that quarter

Government Emergency Ordinances no. 48/2020 (Government of Romania, 2020c) regarding several financial-fiscal measures (M.O. no. 319 of April 16, 2020)

- By derogation from the provisions of art. 169 of Law 207/2015 on the fiscal procedure code, the value added tax requested for reimbursement through the returns with negative amount of VAT with reimbursement option, submitted within the legal submission deadline, is reimbursed by the central fiscal body, with subsequent fiscal inspection. This measure having as consequence the shortening of the time of 
collection of the value added tax to be recovered, representing in fact a fast capital infusion, thus facilitating the obtaining of immediate liquidities for the economic agents in financial difficulty.

Bibliographic documentation made in the specialised literature showed that, there is concern in both the scientific environment and the fiscal administrative apparatus to identify and apply sustainable measures in the centralized financial management of national budgets in times of crisis. These concerns' in order to revive the economy and mitigate the negative economic effects that economic agents are facing in this period of economic crisis.

All these aspects lead to the need for pragmatic approaches to the current economic situation and the identification of viable solutions, mitigating the effects of the pandemic crisis and the economic crisis induced by it. The present study aims to identify some of these viable measures, which, in the opinion of the authors, could be implement with immediate effects on the economic and social environment in Romania.

\section{Methodology}

The analysis performed by the authors is based on the study of the budgetary evolutions of the last 5 concluded financial years and the extrapolation of this financial perspective, of the evolution of the budgetary execution, in the immediate period, respectively 2020 and 2021. In this scientific study, certain potential risk factors identified by the authors were use, as following:

- Factor F1 - Financial pressure on the national budget generated by socio-economic protection measures during the pandemic crisis (PRE)

- Factor F2 - Economic measures adopted at national level to limit the spread of the pandemic, revitalize health management in Romania and retrain hospitals to a new dimension generated by the situation of hospitals during the pandemic (MSE)

- Factor F3 - Measures to relieve economic and financial blockages in the business environment as a result of halting economic activity in the secondary and tertiary sector (MSA)

- Factor F4 - Economic and financial measures adopted in the post-economic crisis for the restart of the economy (MSEF)

Under these circumstances, the authors proceeded to build a centralized database for the last 5 concluded fiscal years, of the budget executions in the national budgets during the studied years, and to make economic predictions based on econometric modelling.

The collected data reflects, up to 2019, sequences of ascending trend in budget revenues, including in the fiscal component, and a moderate increase of the budget deficit, as visible in table 1:

Table 1. Budget execution on national level during 2015-2019

\begin{tabular}{|c|c|c|c|c|c|c|c|c|c|}
\hline Year & UM & GDP & $\begin{array}{c}\text { TOTAL } \\
\text { INCOME } \\
\text { (TI) }\end{array}$ & $\begin{array}{c}\text { Fiscal } \\
\text { incomes } \\
\text { (FI) }\end{array}$ & $\begin{array}{c}\text { Social } \\
\text { contributions } \\
\text { (SC) }\end{array}$ & $\begin{array}{c}\text { Unfiscal } \\
\text { incomes } \\
\text { (NFI) }\end{array}$ & $\begin{array}{c}\text { Total } \\
\text { expences } \\
\text { (TE) }\end{array}$ & $\begin{array}{c}\text { Current } \\
\text { expences } \\
\text { (CE) }\end{array}$ & $\begin{array}{c}\text { Deficite } \\
\text { (D) }\end{array}$ \\
\hline 2015 & mil.euro & 157,167 & 51,673 & 30,567 & 12,734 & 4,318 & 53,802 & 50,044 & 2,129 \\
\hline 2016 & mil.euro & 167,030 & 49,266 & 30,038 & 13,493 & 3,950 & 53,295 & 49,107 & 4,029 \\
\hline 2017 & mil.euro & 180,806 & 54,042 & 30,098 & 15,390 & 4,689 & 59,249 & 55,312 & 5,206 \\
\hline 2018 & mil.euro & 204,206 & 63,309 & 30,556 & 21,034 & 5,830 & 69,066 & 64,394 & 5,757 \\
\hline 2019 & mil.euro & 217,772 & 67,192 & 32,717 & 23,324 & 5,669 & 77,298 & 71,774 & 10,106 \\
\hline \multicolumn{3}{|c|}{ Source: Adaptation of the information regarding budget execution (Ministry of Public Finance, 2020) } \\
\hline
\end{tabular}

It is possible to determine the impact of the disruptive factors in a matrix format for the variables of the budget execution in table 1 , as can be seen in table 2 :

Table 2. Impact of disruptive factors in matrix format for the variables of the budget execution

\begin{tabular}{|c|c|c|c|c|c|c|c|c|c|}
\hline Factors & UM & GDP & $\begin{array}{c}\text { TOTAL } \\
\text { INCOME } \\
\text { (TI) }\end{array}$ & $\begin{array}{c}\text { Fiscal } \\
\text { incomes } \\
\text { (FI) }\end{array}$ & $\begin{array}{c}\text { Social } \\
\text { contributions } \\
\text { (SC) }\end{array}$ & $\begin{array}{c}\text { Unfiscal } \\
\text { incomes } \\
\text { (NFI) }\end{array}$ & $\begin{array}{c}\text { Total } \\
\text { expences } \\
\text { (TE) }\end{array}$ & $\begin{array}{c}\text { Current } \\
\text { expences } \\
\text { (CE) }\end{array}$ & $\begin{array}{c}\text { Deficite } \\
\text { (D) }\end{array}$ \\
\hline F1 & PRE & $-3 \%$ & $-3 \%$ & $-3 \%$ & $-3 \%$ & $-3 \%$ & $10 \%$ & $10 \%$ & $40 \%$ \\
\hline F2 & MSE & $-10 \%$ & $-10 \%$ & $-10 \%$ & $-10 \%$ & $-10 \%$ & $10 \%$ & $10 \%$ & $40 \%$ \\
\hline F3 & MSA & $-7 \%$ & $-7 \%$ & $-7 \%$ & $-7 \%$ & $-7 \%$ & $10 \%$ & $10 \%$ & $40 \%$ \\
\hline F4 & MSEF & $-10 \%$ & $-10 \%$ & $-10 \%$ & $-10 \%$ & $-10 \%$ & $10 \%$ & $10 \%$ & $40 \%$ \\
\hline
\end{tabular}

Source: Own contributions 
The values of the data sequences were predicted for the interval 2020-2021, as can be seen in table 3 :

Table 3. Budget execution on national level predicted based on disruptive factor influence in the interval 2020-2021

\begin{tabular}{|l|c|c|c|c|c|c|c|c|c|}
\hline Year & UM & GDP & $\begin{array}{c}\text { TOTAL } \\
\text { INCOME } \\
\text { (TI) }\end{array}$ & $\begin{array}{c}\text { Fiscal } \\
\text { incomes } \\
\text { (FI) }\end{array}$ & $\begin{array}{c}\text { Social } \\
\text { contributions } \\
\text { (SC) }\end{array}$ & $\begin{array}{c}\text { Unfiscal } \\
\text { incomes } \\
\text { (NFI) }\end{array}$ & $\begin{array}{c}\text { Total } \\
\text { expences } \\
\text { (TE) }\end{array}$ & $\begin{array}{c}\text { Current } \\
\text { expences } \\
\text { (CE) }\end{array}$ & $\begin{array}{c}\text { Deficite } \\
\text { (D) }\end{array}$ \\
\hline 2020 & mil.euro & 193,138 & 47,969 & 22,568 & 16,089 & 3,910 & 83,244 & 77,801 & 35,275 \\
\hline 2021 & mil.euro & 198,698 & 49,350 & 23,218 & 16,552 & 4,023 & 82,325 & 76,991 & 32,975 \\
\hline \multicolumn{7}{|c|}{ Source: Own contributions }
\end{tabular}

Prospective methods were used to achieve the objectives of the study, respectively:

- Objective 1 - Defining and conceptualizing the econometric model

- Objective 2 - Identifying the set of viable solutions

- Objective 3 - Implementation of the national economy and the national budget for the period 20202021

- Objective 4 - Assessing the impact of applying these measures

Taking into account the established objectives, the authors of the research suggest the following working hypotheses:

- Hypothesis 1 - The impact of the pandemic has a direct effect on the national economy with a slowdown in economic recovery equivalent to a cycle of eliminating the biological threat and a cycle of eliminating the effects on regular trade on the Romanian market;

- Hypothesis 2 - We estimate that the effect of F1-F4 factors is directly proportional to the damage of the economy, during the pre-pandemic crisis, by devaluation of the national currency and decrease of the economic growth slope due to factors external to the business environment;

- Hypothesis 3 - The effect of implementing economic recovery measures is viable if and only if global stabilisation solutions are identified through specific methods of financial management, both at the level of the economic agents and at the level of competent public authorities in Romania;

Dedicated statistical programs were used to demonstrate the working hypotheses: Gretl software (2019 version) and programs for performing statistical descriptive tests based on the calculation of the main frequency sequences and inflection points based on simple regressions (Excel, Microsoft Access).

The results of centralising the database allowed obtaining a model with statistical significance of over $99 \%$, which reflects the fact that under the action of F1-F4 disruptive factors the impact of budget execution is affect by economic deficit.

Statistical data reflect the fact that the economy responds to financial stress through economic rebound, and this rebound is maximize by the social rebound amid the pandemic management at the level of the existing capacities in the health segment in Romania.

At the end of the emergency state and the 30-day alert period, it is estimate that the medical system will be overloaded. The direct effect of limiting social distancing measures and eliminating population traffic restrictions being the increase of the incidence rate and implicitly of social stress on the national budget through its health budget component and through its financial component allocated strictly to economic recovery.

The model demonstrates the working hypotheses: a direct correlation between the three hypotheses was identify.

The model equation is presented below and reflects the homogeneous characteristic of the database, the correlation of the data series after applying the adjustment related to the disruptive factors (formula 1)

$$
\begin{aligned}
& { }^{\wedge} \mathrm{D}=+2,12 \mathrm{e}-013 * \text { GDP }-1,00 * \mathrm{TI}+1,00 * \mathrm{TE} \\
& (3,53 e-013)(6,70 e-013)(4,44 e-013) \\
& T=7, R \text {-squared }=1,000 \text { (standard errors in parentheses) }
\end{aligned}
$$

The model used by the authors is based on applying the method of the smallest squares in two phases on the budget deficit dependent variable and the total revenues, total expenditures and GDP regressors. The regression coefficients highlight the negative impact of total revenues on the budget deficit after applying the adjustments related to disruptive factors and the positive impact of GDP estimated by the authors as showing resistance to deceleration through the passive component of the economy of rigidity to the influence of disruptive factors.

The statistical tests presented below indicate high statistical significance of total budget revenues and total expenditures on the budget deficit dependent variable according to the instrumented variables, fiscal revenues, social contributions and non-fiscal revenues, as part of total budget revenues. 
Model 1: TSLS, using the observations 2015-2021 ( $\mathrm{T}=7$ )

Dependent variable: D

Instrumented: GDP, TI, TE

Instruments: FI, SC, NFI

\begin{tabular}{lccccc}
\multicolumn{1}{c}{ Coefficient } & Std. Error & t-ratio & $p$-value & \\
GDP & $2,12132 \mathrm{e}-013$ & $3,53157 \mathrm{e}-013$ & 0,6007 & 0,5804 & \\
TI & $-1,00000$ & $6,70141 \mathrm{e}-013$ & $-1,492 \mathrm{e}+012$ & $<0,0001$ & $* * *$ \\
TE & 1,00000 & $4,43751 \mathrm{e}-013$ & $2,254 \mathrm{e}+012$ & $<0,0001$ & $* * *$ \\
Mean dependent variable & 65949,09 & S.D. dependent variable & 70162,29 \\
The sum of the squares of & $1,97 \mathrm{e}-16$ & Standard regression error & $7,02 \mathrm{e}-09$ \\
the residues & & & & \\
Uncentred R-squared & 1,000000 & Centred R-squared & & 0,355991 \\
F(3, 4$)$ & $2,77 \mathrm{e}+26$ & P-value(F) & & $4,34 \mathrm{e}-53$
\end{tabular}

Null Hypothesis: OLS Estimations are consistent

Asymptotic Statistical Test: Chi square (3) $=7,0008$

with $\mathrm{p}$-value $=0,0718722$

Pesaran-Taylor Test for heteroskedasticity -

Null Hypothesis: heteroskedasticity is not present

Asymptotic Statistical Test : $\mathrm{z}=1$, \#INF

with $\mathrm{p}$-value $=2,22045 \mathrm{e}-016$

Weak instrument test -

Cragg-Donald minimum eigenvalue $=0,15362$

Statistical estimates for testing errors in the null hypothesis show that OLS estimates are consistent, heteroskedasticity is not present, the correlation function of the residues indicating significance at the low error threshold of $1 \%$.

The predicted distribution of the budget deficit assimilated to the financial stress function reflects an increase of the dependent variable under the impact of the disruptive factors, the trend values being perfectly correlated with the predicted values on a $95 \%$ confidence interval, as according to figure 1 :

Figure 1. Prediction Table 95\% Confidence Interval, z $(0,025)=1.96$

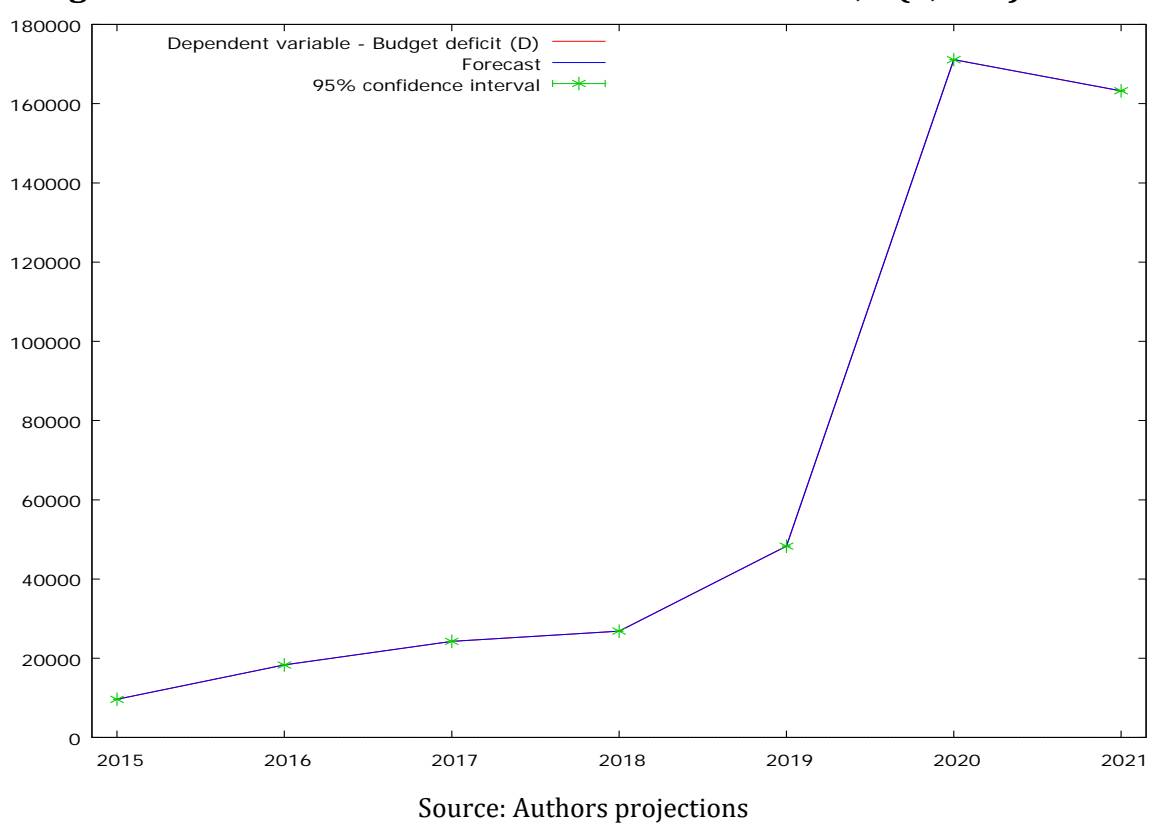

The modelled data indicate that the model is homogeneous, well determined and representative for the studied phenomenon, respectively the maximization of the financial stress function under the influence of the disruptive factors generated by the propagation of the coronavirus pandemic in Romania. 


\section{Results of the study}

- The analysis performed by the authors on the future budget execution in the period 2020-2021 indicates the exposure of the national economy to financial stress, the entry into the period of economic recession and indirectly the stopping of economic growth. This demonstrates the validity of the working hypotheses formulated, namely:

- Hypothesis 1 - The impact of the pandemic has a direct effect on the national economy with a slowdown in economic recovery equivalent to a cycle of eliminating the virological threat and a cycle of eliminating the effects on regular trade on the Romanian market;

- Hypothesis 2 - It is estimated that the effect of F1-F4 factors is directly proportional to the damage of the economy, during the pre-pandemic crisis, by devaluation of the national currency and decrease of the economic growth slope due to factors external to the business environment;

- Hypothesis 3 - The effect of applying economic recovery measures is viable if and only if global stabilisation solutions are identified through specific methods of financial management, both at the level of economic agents and at the level of competent public authorities in Romania;

In order to identify solutions of economic stabilisation, the authors elaborated a management screening based on the scenario method, screening that can be centralize as in figure 2 :

Figure 2. Results of management screening and proposed solutions

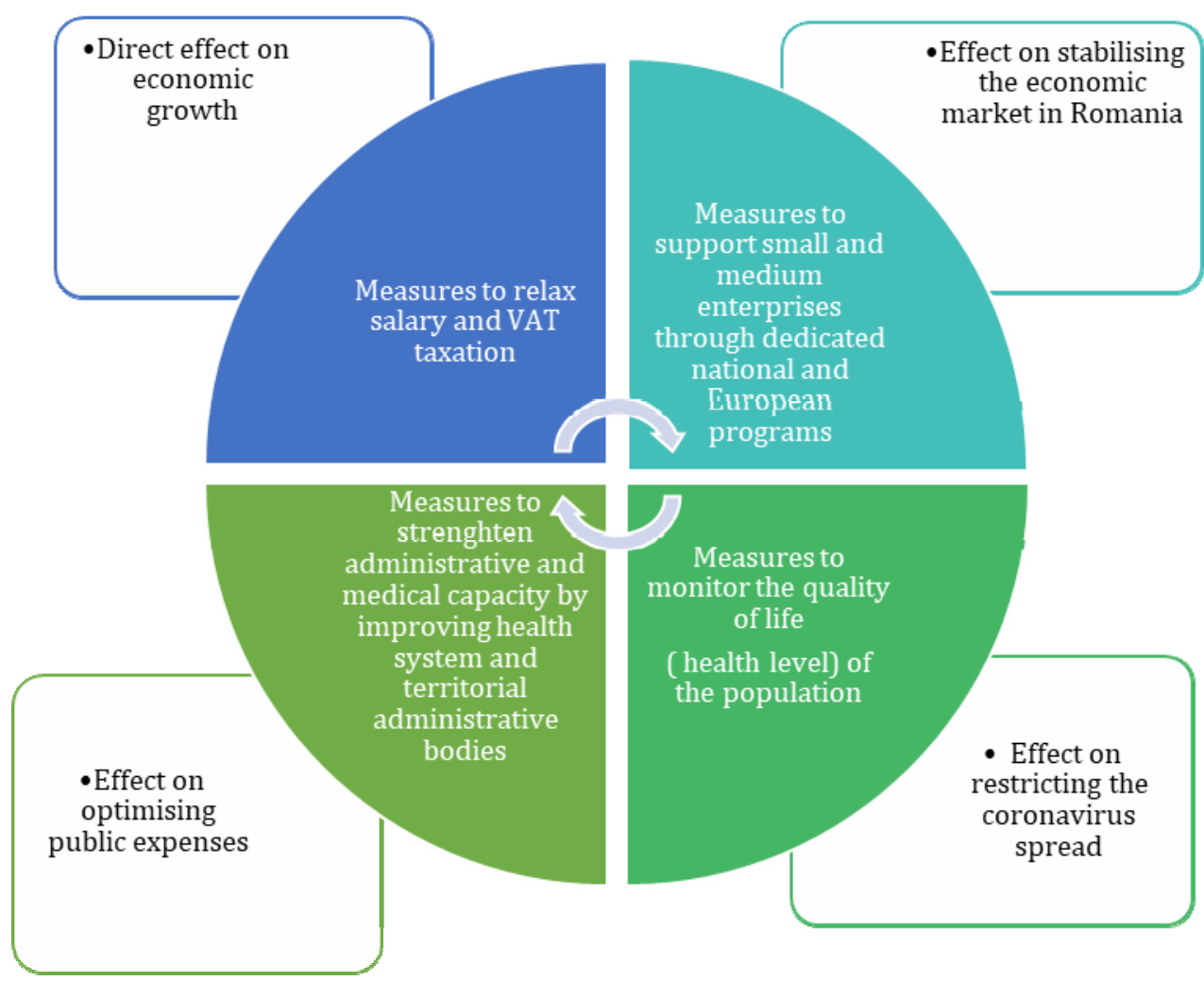

Source: Author`s contributions

The scientific approach demonstrates, through the chronology of the study stages and the validity of the obtained results, the objectives proposed for the study as follows:

- Objective 1 - Defining and conceptualizing the econometric model - an econometric model was designed, based on the method of the smallest squares in two phases, a model that proved to be viable, representative of the phenomenon of financial stress analysed, under conditions of coronavirus pandemic in Romania;

- Objective 2 - Identifying the set of viable solutions - a set of 4 viable solutions was identified by applying the scenario method, solutions that will have the effect of improving in four strategic directions the national economy as a whole;

- Objective 3 - The implementation of the national economy and the national budget for the period 2020-2021 - the budget executions for the period 2020-2021 were predicted by applying the trend curves adjusted with the influence of the disruptive factors presented in the methodology chapter; 
- Objective 4 - Evaluating the impact of applying these measures - the impact of applying these measures to the strategic directions for restarting the economy was evaluated and an impact diagram was designed.

\section{Conclusions}

The study conducted by the authors refers to the current conditions in Romania regarding the onset of the coronavirus pandemic, the entry into the recession period, the need to restart the economy through viable measures and solutions.

The authors highlighted the impact of disruptive factors on the financial stress function applied to the national budget and its execution.

The results of the study are useful to the profile institutions in Romania and to the economic agents in identifying the approaches and strategies that could be adopted at macro and microeconomic level for economic recovery after the coronavirus pandemic crisis.

The limitations of the study are due to a relatively small number of variables introduced in the modelling with the mention that they can be extended in further research in order to detail more accurately the effects of the pandemic on the national economy with a view to identify a complementary set of viable solutions.

\section{Acknowledgment}

„This work is supported by the project ANTREPRENORDOC, in the framework of Human Resources Development Operational Programme 2014-2020, financed from the European Social Fund under the contract number 36355/23.05.2019 HRD OP /380/6/13 - SMIS Code: 123847."

\section{References}

1. Anderson, R. M., Heesterbeek, H., Klinkenberg, D., \& Hollingsworth, T. D. (2020). How will country-based mitigation measures influence the course of the COVID-19 epidemic? The Lancet, 395(10228), 931-934. https://doi.org/10.1016/S0140-6736(20)30567-5

2. Antohi, V. M., Zlati, M. L., Sarbu, R., Stanciu, S., Varlanuta, F. O., , Anagnoste, S., (2019). Approaches regarding the Management of Food Policies in the Context of the African Swine Fever Crisis based on a Food Sustainability Statistical Model. Amfiteatrul Economic, 21(51), 329.

3. Atkeson, A. (2020). What Will Be the Economic Impact of COVID-19 in the US? Rough Estimates of Disease Scenarios. NBER Working Paper Series, 25. Retrieved from http://www.nber.org/papers/w26867

4. Barro, R., Ursua, J., \& Weng, J. (2020). The Coronavirus and the Great Influenza Epidemic-Lessons from the. Retrieved from https://papers.ssrn.com/sol3/papers.cfm?abstract_id=3556305

5. Ferguson, N. M., Laydon, D., Nedjati-Gilani, G., Imai, N., Ainslie, K., Baguelin, M., ... Ghani, A. C. (2020). Impact of non-pharmaceutical interventions (NPIS) to reduce COVID-19 mortality and healthcare demand. Imperial.Ac.Uk, (March), 3-20. https://doi.org/10.25561/77482

6. Guvernul Romaniei. (2020a). Ordonanța de urgență nr. 29/2020 privind unele măsuri economice și fiscal-bugetare. Retrieved April 20, 2020, from https://static.anaf.ro/static/10/Anaf/Informatii_R/oug_29_21032020.pdf

7. Guvernul Romaniei. (2020b). Ordonanța de urgență nr. 33/2020 privind unele măsuri fiscale și modificarea unor acte normative. Retrieved April 21, 2020, from http://www.imm.gov.ro/wp-content/uploads/2020/04/OUG-33-2020.pdf

8. Guvernul Romaniei. (2020c). ORDONANŢ̆ DE URGENŢ̆ Nr. 48/2020 din 9 aprilie 2020 privind unele măsuri financiar-fiscale. Retrieved April 21, 2020, from https://static.anaf.ro/static/10/Anaf/legislatie/OUG_48_2020.pdf

9. McKibbin, W. J., \& Fernando, R. (2020). The Global Macroeconomic Impacts of COVID-19: Seven Scenarios. SSRN Electronic Journal, (March), 1-43. https://doi.org/10.2139/ssrn.3547729

10. Ministerul Finantelor Publice. (2020). Informaţii execuţie bugetară. Retrieved April 25, 2019, from https://www.mfinante.gov.ro/execbug.html?pagina=domenii

11. Stanciu, S., (2015), Food of Animal Origin - Production and Safety Incidents in Romania, Lambert Academic Publishing Saarbrucken, Germany, ISBN 978-3-659-77272-6

12. Stanciu, S., Virlanuta, F.O., Vochin, O.A., Ionescu, R.V., Antohi, V.M., 2019, Fast Moving Consumer Goods (FMCG) Market in Romania Features and Trends, Amfiteatru Economic, 21/Special Issue 13, pp. 778-794, 